\title{
The first occurrence of the ctenophore Mnemiopsis leidyi in the North Sea
}

\author{
Maarten Boersma • Arne M. Malzahn • Wulf Greve • \\ Jamileh Javidpour
}

Received: 4 December 2006 / Revised: 13 December 2006 / Accepted: 13 December 2006 / Published online: 12 January 2007

(C) Springer-Verlag and AWI 2007

\begin{abstract}
After the discovery of large densities of Mnemiopsis leidyi in the Baltic Sea near Kiel by Javidpour et al. (First record of Mnemiopsis leidyi A. Agassiz 1865 in the Baltic Sea, 2006) in October 2006, we investigated the gelatinous zooplankton in the North Sea near Helgoland and recorded Mnemiopsis leidyi for the first time in the North Sea, albeit in much lower densities than those recorded in the Baltic Sea.
\end{abstract}

Keywords Neozoa Invasive species $\cdot$ German bight . Helgoland roads $\cdot$ Beroe $\cdot$ Black Sea

\section{Introduction}

On 17 October 2006, a swarm of the lobate ctenophore Mnemiopsis leidyi was observed for the first time dur-

Communicated by H.-D. Franke.

M. Boersma $(\bowtie) \cdot$ A. M. Malzahn

Biologische Anstalt Helgoland,

Alfred Wegener Institute for Marine and Polar Research,

P.O. Box 180, 27483 Helgoland, Germany

e-mail: Maarten.Boersma@awi.de

M. Boersma

GKSS Research Centre,

Institute for Coastal Research,

Max-Planck-Straße 1, 21502 Geesthacht, Germany

W. Greve

German Centre for Marine Biodiversity

Research (Senckenberg Research Institute),

Notkestr. 85, 22607 Hamburg, Germany

J. Javidpour

Leibniz-Institute of Marine Sciences,

Düsternbrookerweg 20, 24105 Kiel, Germany ing regular sampling of the Baltic Sea near Kiel, Germany (Javidpour et al. 2006). This news was met with a combination of scepticism and apprehension, as Mnemiopsis leidyi has gathered quite a reputation as a biological invader. Originally, a species from the Western Atlantic (Purcell et al. 2001), occupying coastal waters over a wide latitudinal range $\left(40^{\circ} \mathrm{N}-46^{\circ} \mathrm{S}\right)$, it invaded the Black Sea in the 1980 s, followed by subsequent invasions of the other large water bodies in the Mediterranean basin (Shiganova et al. 2001). The consequences of these invasions for the systems were drastic. Predators of $M$. leidyi were not present in these seas and, as a result, populations developed to very high densities (Kideys et al. 2000). M. leidyi is a voracious predator on zooplankters, as well as on fish eggs and larvae (Reeve et al. 1978; Kremer 1979). The mass occurrence of M. leidyi in the Black Sea and Caspian Sea coincided with a sharp decline in the yields of fisheries (Bilio and Niermann 2004).

As there is intense water exchange between the North Sea and the Western Baltic Sea, and another ctenophore Pleurobrachia pileus is known to be transported into the Baltic from the Belt Sea or Skagerak (Schneider 1987), it is of utmost importance to assess whether M. leidyi has also invaded the North Sea.

\section{Methods}

We sampled the gelatinous zooplankton on the Helgoland Roads station $\left(54^{\circ} 11.18^{\prime} \mathrm{N}\right.$ and $\left.07^{\circ} 54.00^{\prime} \mathrm{E}\right)$, the same station that has been sampled for the long-term series of zooplankton (Greve et al. 2004), phytoplankton and nutrients (Wiltshire and Manly 2004) for the last $30-40$ years. The sampling station is located between 
the Island of Helgoland and the adjacent sandy island in the German Bight, North Sea. The water depth at the station is approximately $10 \mathrm{~m}$ and the water column is mixed throughout the year due to strong tidal currents (up to 1.5 knots). After subtraction of tidal currents, the counterclockwise residual flow direction in the area is northerly from the English Channel to the northern North Sea. Salinity is fairly constant, varying between 30 and 33, and temperature ranges from 2 to $20^{\circ} \mathrm{C}$.

Lobate ctenophores such as M. leidyi and the naturally occurring Bolinopsis infundibulum are notoriously difficult to fixate, as they disintegrate rapidly as a result of fixation. Therefore, in the standard long-term zooplankton samplings, these organisms were recorded only until the early 1980s. Bolinopsis was found almost exclusively in the months July-September.

A CalCOFI ring trawl with a $500 \mu \mathrm{m}$ mesh net (aperture $100 \mathrm{~cm}$, length $400 \mathrm{~cm}$, equipped with a flowmeter) was towed for $15 \mathrm{~min}$ from a research vessel, resulting in a sampled volume of water of around $500 \mathrm{~m}^{3}$. The samples were transferred to the laboratory, and the ctenophores were sorted out immediately.

\section{Results and discussion}

On 30 November 2006, our first day of sampling following the discovery of $M$. leidyi in the Kiel Bight, we caught several ctenophores in the North Sea near Helgoland, which were identified as M. leidyi. Weather conditions prevented quantitative sampling. Quantitative sampling on 5 and 6 December 2006 yielded densities of around 0.1 individuals of $M$. leidyi $\mathrm{m}^{-3}$, mostly in the size range of $1-2.5 \mathrm{~cm}$. These densities were much lower than the ones reported for the Baltic Sea (80 $\mathrm{m}^{-3}$ Javidpour et al. 2006). Nevertheless M. leidyi has also reached the southern North Sea.

At this moment, it is not possible to assess the potential impact of M. leidyi on the plankton community of the southern North Sea, as we do not know how the density of this organism is going to change. Most likely, however, the impact on the system will be less than in the Black Sea and Caspian Sea. First of all, two species of the ctenophore genus Beroe occur in the German Bight. This genus is known to feed selectively on other ctenophores with which they co-evolved (Greve et al. 1976). B. ovata is the major predator of $M$. leidyi in the native habitat, and since the accidental introduction of $B$. ovata into the Black Sea, population densities of $M$. leidyi have decreased and seem to be under predation control. B. cucumis, the predator of
B. infundibulum in the North Sea, will probably feed on $M$. leidyi, and so may B. gracilis, the predator of Pleurobrachia pileus in the North Sea. This should constrain the mass development of $M$. leidyi populations to some extent. Secondly, according to Shiganova et al. (2001), M. leidyi does not survive at temperatures lower than $4^{\circ} \mathrm{C}$ in the Black Sea. Water temperature at Helgoland Roads at the moment of sampling was $10^{\circ} \mathrm{C}$, but typically goes to $2-3^{\circ} \mathrm{C}$ in February (Wiltshire and Manly 2004). This would mean that local survival of the populations at least in the surface waters of the southern North Sea may not be likely (see also Esser et al. 2004) and that future populations either need to find appropriate winter refugia or need to be seeded by overwintering populations from somewhere else. However, global warming may prevent this control of the invader, which in turn could result in elevated grazing pressure on overwintering holoplankters.

Even though predation rates of $M$. leidyi are large and certainly gravely affected zooplankton densities in the Black Sea (Kideys 2002) and Caspian Sea, some authors suggest that the yields of fisheries in the Black Sea primarily declined as a result of overfishing, which freed up the zooplankton production to be used by Mnemiopsis rather than the reverse (Gucu 2002). This means that $M$. leidyi in the Black Sea could have been present long before actually reaching the high densities. Only when conditions were favourable, i.e., less competition by juvenile fish and high primary production as a result of eutrophication, did the mass development occur (Gucu 2002). This mass development of M. leidyi then decreased the fish stocks even more. A similar phenomenon might have occurred in the North Sea. It is most likely that M. leidyi has also been present in the North Sea at low densities for quite some time, and used a loophole opened recently by historically low stock sizes of one of the most important planktivorous fish in the North Sea, lesser sandeel (Ammodytes marinus). Sandeel plays a pivotal role as prey for piscivorous fish, sea birds and marine mammals. On top of that, large fisheries exists for this species, which until fairly recently was classified as sustainable by ICES (ICES 2002). Sandeel is responsible for around $1 / 3$ of the commercial fish landings from the North Sea, with landings increasing from 0.2 million tons year ${ }^{-1}$ to over 1 million tons year ${ }^{-1}$ in the 1990 s. The enormous increase in fisheries on this important planktivore has caused the stocks to decline dramatically (Arnott and Ruxton 2002), causing a closure of the fisheries in 2005. It is possible that the decrease in sandeel standing stock, and the other planktivorous fish stocks that had been depleted before in the North Sea, has released the competitive pressure on M. leidyi 
to an extent, which has allowed this species to develop densities high enough to be noticed in sampling. All this needs further research.

Mnemiopsis leidyi has arrived in the North Sea; at this moment, we do not know how and from where. The densities observed by us and especially those in the Baltic Sea (Javidpour 2006) are, however, so high that we can exclude a single recent ballast water release event. It is another example of the invasions of biological species in this part of the world that might severely affect the ecosystem (Diederich 2006). We will have to keep our finger at the pulse of this sensitive ecosystem to be able to make predictions of the impact of this new species in the North Sea.

Note added in proof: Since the acceptance of this paper, Mnemiopsis has also been found in the coastal waters of the Netherlands (Faasse and Bayha 2006) and of the Swedish coast (Hansson 2006).

\section{References}

Arnott SA, Ruxton GD (2002) Sandeel recruitment in the North Sea: demographic, climatic and trophic effects. Mar Ecol Prog Ser 238:199-210

Bilio M, Niermann U (2004) Is the comb jelly really to blame for it all? Mnemiopsis leidyi and the ecological concerns about the Caspian Sea. Mar Ecol Prog Ser 269:173-183

Diederich S (2006) High survival and growth rates of introduced Pacific oysters may cause restrictions on habitat use by native mussels in the Wadden Sea. J Exp Mar Biol Ecol 328:211227

Esser M, Greve W, Boersma M (2004) Effects of temperature and the presence of benthic predators on the vertical distribution of the ctenophore Pleurobrachia pileus. Mar Biol 145:595601

Faasse MA, Bayha KM (2006) The ctenophore Mnemiopsis leidyi A. Agassiz 1865 in coastal waters of the Netherlands: an unrecognized invasion? Aquat Invasions 1:270-277
Greve W, Reiners F, Nast J, Hoffmann S (2004) Helgoland Roads meso- and macrozooplankton time-series 1974 to 2004: lessons from 30 years of single spot, high frequency sampling at the only off-shore island of the North Sea. Helgol Mar Res 58:274-288

Greve W, Stockner J, Fulton NJ (1976) Towards a theory of speciation in Beroe. In: Meckie G (ed) Coelenterate ecology and behaviour. Plenum Press, New York pp 251-258

Gucu AC (2002) Can overfishing be responsible for the successful establishment of Mnemiopsis leidyi in the Black Sea? Estuar Coast Shelf Sci 54:439-451

Hansson HO (2006) Ctenophores of the Baltic and adjacent seas-the invader Mnemiopsis is here! Aquat Invasions 1:295-298

ICES (2002) Report of the fishery management advisory commitee. ICES Cooperative Research Report 236:1-416

Javidpour J, Sommer U, Shiganova TA (2006) First record of Mnemiopsis leidyi A. Agassiz 1865 in the Baltic Sea. Aquat Invasions 1:299-302

Kideys AE (2002) Ecology: fall and rise of the Black Sea ecosystem. Science 297:1482

Kideys AE, Kovalev AV, Shulman G, Gordina A, Bingel F (2000) A review of zooplankton investigations of the Black Sea over the last decade. J Mar Syst 24:355-371

Kremer PM (1979) Predation by the ctenophore Mnemiopsis lei$d y i$ in Narragansett Bay, Rhode Island. Estuaries 2:97-105

Purcell JE, Shiganova TA, Decker MB, Houde ED (2001) The ctenophore Mnemiopsis in native and exotic habitats: US estuaries versus the Black Sea basin. Hydrobiologia 451:145-176

Reeve MR, Walter MA, Ikeda T (1978) Laboratory studies of ingestion and food utilization in lobate and tentaculate ctenophores. Limnol Oceanogr 23:740-751

Schneider G (1987) Role of advection in the distribution and abundance of Pleurobrachia pileus in Kiel Bight. Mar Ecol Prog Ser 41:99-102

Shiganova TA, Mirzoyan ZA, Studenikina EA, Volovik SP, Siokou-Frangou I, Zervoudaki S, Christou ED, Skirta AY, Dumont HJ (2001) Population development of the invader ctenophore Mnemiopsis leidyi, in the Black Sea and in other seas of the Mediterranean basin. Mar Biol 139:431-445

Wiltshire KH, Manly BFJ (2004) The warming trend at Helgoland Roads, North Sea: Phytoplankton response. Helgol Mar Res 58:269-273 